\title{
Risk Economic Viability Focusing on Energy Efficiency in Three Genotypes of Elephant Grass in the Municipality of Alegre, Brazil
}

\author{
Wanessa Francesconi Stida ${ }^{1}$, Rogério Figueiredo Daher ${ }^{1}$, José Augusto de Almeida Sant'Ana ${ }^{2}$, \\ Niraldo José Ponciano ${ }^{1}$, Eduardo Peres Furlani ${ }^{3}$, Ana Kesia Faria Vidal ${ }^{1}$, Rafael Souza Freitas ${ }^{1}$, \\ Wallace Luís de Lima ${ }^{2}$, Antônio Alonso Cecon Novo ${ }^{4}$, Paulo Ricardo dos Santos ${ }^{5}$, \\ Sebastião Décio Coimbra de Souza ${ }^{1}$, César Otaviano Penna Júnior ${ }^{2}$, Erik da Silva Oliveira ${ }^{6}$, \\ Alexandre Gomes de Souza ${ }^{1}$, Raiane Mariani Santos ${ }^{1}$, Maxwel Rodrigues Nascimento ${ }^{1}$ \\ \& Josefa Grasiela Silva Santana ${ }^{1}$
}

\footnotetext{
${ }^{1}$ Universidade Estadual do Norte Fluminense Darcy Ribeiro, Campos dos Goytacazes, RJ, Brazil

${ }^{2}$ Instituto Federal de Educação, Ciência e Tecnologia do Espírito Santo, Alegre, ES, Brazil

${ }^{3}$ Universidade Federal de Juiz de Fora, Juiz de Fora, MG, Brazil

${ }^{4}$ Instituto Federal Fluminense, Bom Jesus do Itabapoana, RJ, Brazil

${ }^{5}$ Universidade Federal do Cariri, Crato, CE, Brazil

${ }^{6}$ Universidade Iguaçu, Campus V, Itaperuna, RJ, Brazil

Correspondence: Wanessa Francesconi Stida, Universidade Estadual do Norte Fluminense Darcy Ribeiro, Campos dos Goytacazes, RJ, Brazil. E-mail: w.stida@hotmail.com
}

Received: December 27, 2020

Accepted: February 1, $2021 \quad$ Online Published: March 15, 2021

doi:10.5539/jas.v13n4p138

URL: https://doi.org/10.5539/jas.v13n4p138

\begin{abstract}
The use, on a large scale, of fossil fuels and their derivatives has devastating long-term consequences for mankind. Therefore is an urgent need to seek new alternatives for sustainable energy production. This fact is one of the great challenges to be faced by researchers worldwide. Within this context, the elephant grass has been standing out successfully in the production of biomass for energy purposes. The purpose in this study was to analyze the economic viability of biomass production of three genotypes of elephant grass for energy purposes and to identify the risk by means of the Monte Carlo simulation. The economic indicators were obtained by calculating the Net Present Value (NPV), the Internal Rate of Return (IRR), and the Profitability Index (PI). To determine the degree of uncertainty, analysis of sensitivity was applied. Results indicated viability for all genotypes, especially the Guaçú/I.Z.2, with IRR of $17.79 \%$. Variation in sale price of grass generates a greater impact on profitability, followed by the labor and fertilization costs. The risk of failure was relatively low, with the exception of Capim Cana D'África, 38.16\%. Among the three genotypes studied, the G1 genotype (Guaçú/I.Z.2) stood out as the one with the best economic viability.
\end{abstract}

Keywords: production costs, biomass, Cenchrus purpureus (Schumach.) Morrone

\section{Introduction}

Global energy demand has grown throughout the years, an increase related to industrial production, population growth, new energy using technologies, among other factors. As a result, countries seek to develop new technologies to meet growing demand. The use of alternative renewable sources is a sustainable solution. From this perspective, plant biomass offers economic and environmental advantages since, in addition to generating clean energy, it contributes, through photosynthesis, to the reduction of the greenhouse effect in the reprocessing of $\mathrm{CO}_{2}$ emissions (Morais et al., 2009).

Elephant grass [Cenchrus purpureus (Schumach.) Morrone] has stood out as one of the main crops for this purpose for having a high photosynthetic efficiency and high capacity for production of dry matter and fiber content (Morais et al., 2009; Santos et al., 2014; Mohammed et al., 2015). In addition, it presents high yield, rapid plant growth, high hardiness and resistance to unfavorable climatic conditions, short cycle, and biomass quality attributes (Paterlini et al., 2013). 
Trends in the renewable energy market illustrate the strong growth and investments in all market sectors (REN 21, 2013). Brazil is seen as one of the largest agricultural producers and the largest producer and consumer of bioenergy worldwide. Rich biodiversity, availability of land for crops, and adequate climatic conditions are factors that have contributed to high levels of biomass use (Van der Selt, 2011). As such, Brazil is one of the countries with the greatest abundance of renewable energy globally (Borges et al., 2016).

For Ross, Westerfield, and Jordan (2008), a project or investment is worthwhile when it creates value for its owners. For this, it is essential to market what is produced for a price greater than the cost of obtaining it. But for long-term investments (longer than one year), it is also necessary to consider the value of money over time. That is why decision support tools, such as the Net Present Value (NPV), the Internal Rate of Return (IRR), and the Profitability Index (PI), should be used to evaluate the economic viability of an investment.

The relevance of the economic viability analysis of elephant grass relies on the fact that one can measure yield variation with a view to its increase, with a minimum associated cost, optimizing, therefore, the system as a whole. The financial analysis is based on estimates of cash flows, in which the variables involved in the systems are predictable and lead to deterministic financial indicators. In the analysis of economic viability, an attempt is made to identify bottlenecks that generate possibilities to make the success of the project unviable and, thereby, neutralize them, making it possible for its objective to be achieved effectively, not depending on chance, but rather on concrete and effective actions based on the studies performed. A number of authors state that these indexes are used to perform a financial and risk analysis (Aerieira et al., 2008; Lyra et al., 2010; Pereira et al., 2011; Sabbag \& Nicodemo, 2011; Ferraz Carvalho et al., 2014).

Given this, the goal of this study was to determine the profitability of dry matter yield of elephant grass biomass for energy purposes, calculating the NPV, IRR, and PI, and evaluating, by sensitivity and risk analyses, the economic viability of planting three genotypes of elephant grass.

\section{Method}

The experiment was conducted at the facilities of the Instituto Federal do Espírito Santo - campus Alegre, in the

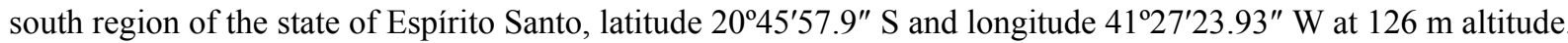
According to the Köppen classification (1948), the climate is of "Cwa" type, i.e., tropical hot and humid, with cold, dry winter. It has an average annual temperature of $23.1{ }^{\circ} \mathrm{C}$ and total annual precipitation of $1341 \mathrm{~mm}$ (Lima et al., 2008).

The soil in the experimental area is classified as Eutrophic Red Yellow Latosol (Embrapa, 2013). Soil samples were collected at a $0-20 \mathrm{~cm}$ depth at the site selected for the experiment, to perform particle size analysis, which resulted in Area I: Sand 80.25\%, Silt 2.75\%, and Clay 17.0\%; in Area II: Sand 78.55\%, Silt 2.4\%, and Clay 19.05\%; and, in Area II: Sand 69.95\%, Silt 2.4\%, and Clay 27.65\%, performed by the Laboratory of Soil Physics of the Center for Agricultural Sciences of the Universidade Federal do Espírito Santo, located in the municipality of Alegre, state of Espírito Santo, Brazil.

This study was conducted with the genetic material from the Germplasm Bank of the Universidade Estadual do Norte Fluminense Darcy Ribeiro, located in the municipality of Campos dos Goytacazes, state of Rio de Janeiro, Brazil. Three genotypes of elephant grass (G1: Guaçú/I.Z.2; G2: Cameroon Piracicaba; and G3: Capim Cana D'África) were selected and tested in a randomized block design with three replicates, in the arrangement of sub-subdivided plots, to verify the potential of genotypes under five levels of nitrogen fertilization and four of phosphate fertilization.

The experimental area was composed of 36 lines of $12 \mathrm{~m}$ each and $1.5 \mathrm{~m}$ line spacing. Each block comprised 60 experimental units of $2.40 \mathrm{~m}$ of linear extension. Stem planting was arranged in line in furrows, joining tip and tail of each other. After that, stems were cut to approximately 50 to $60 \mathrm{~cm}$ in size inside the planting furrow and covered with $3 \mathrm{~cm}$ of soil.

The experiment was installed in April 2010. Two standardization cuts were made on October 19, 2010 and March 2, 2011, respectively, for climatic factors and failures found in the planting. Three evaluation cuts were performed, the first, on August 29, 2010; the second, on June 25, 2011; and the third evaluation cut was performed on December 22, 2011.

\subsection{Economic Viability Analysis}

The economic viability analysis was initiated with the construction of cash flows, which enabled to calculate profitability indicators for the activity under consideration. As Noronha (1987) states, the revenues and expenditures of financial resources in a particular project along time represent its cash flow. The effective 
revenues form the inflows and the effective expenditures form the outflows, in which the differential is given by net flow (Ponciano et al., 2004).

\subsection{Net Present Value and Internal Rate of Return}

Net Present Value (NPV) represents the sum of the present value of the expected net cash flows for each period brought to the zero period, at a discount rate (r) equal to the minimum attractiveness rate (Guiducci et al., 2012). Thus, the NPV calculation has the following formula:

$$
\mathrm{NPV}=\sum_{\mathrm{t}-1}^{\mathrm{n}} \frac{\mathrm{CF}_{\mathrm{t}}}{(1+\mathrm{r})^{\mathrm{t}}}-\mathrm{CF}_{0}
$$

where, $\mathrm{CF}_{0}=$ initial investment made in the period $\mathrm{t}=0 ; \mathrm{CFt}=$ expected net cash flow in the period $\mathrm{t}=0 ; \mathrm{r}=$ discount rate.

When the value found for the NPV of a project is positive, it is considered the project should be able to generate value for the owners; hence, it should be accepted, because the greater the value found, the greater the possibility of generating wealth. For that reason, when two projects with the same level of risk are analyzed, the rational choice is invariably for the project with the highest NPV. In case the value found is negative, the project must be rejected, because the smaller the NPV, the greater the loss for the owners. If the NPV equals zero, however, its implementation, or not, makes no difference, because the project is unable to generate or destroy wealth (Ross, Westerfield, \& Jordan, 2008).

The Internal Rate of Return (IRR) is the discount rate that equals to zero the NPV of an investment opportunity. This means, in practice, the IRR provides the highest acceptable discount rate for the project under analysis to be profitable because it makes the present value of net cash flows to be equal to the initial cost of implementing the project (Lyra et al., 2010; Guiducci et al., 2012; Ferraz Carvalho et al., 2014). As such, mathematically, the IRR is represented following the equation:

$$
\begin{gathered}
\mathrm{NPV}=\sum_{\mathrm{t}-1}^{\mathrm{n}} \mathrm{CF}_{\mathrm{t}} /(1+\mathrm{IRR})^{\mathrm{t}}-\mathrm{CF}_{0}=0 \\
\sum_{\mathrm{t}-1}^{\mathrm{n}} \mathrm{CF}_{\mathrm{t}} /(1+\mathrm{IRR})^{\mathrm{t}}=\mathrm{CF}_{0}
\end{gathered}
$$

where, $\mathrm{CF}_{0}=$ initial investment made in the period $\mathrm{t}=0 ; \mathrm{CF}_{\mathrm{t}}=$ expected net cash flow in period $\mathrm{t}$; IRR $=$ Internal Rate of Return.

Under the IRR method, a project must be executed if the value found is greater than the cost of capital of the project owners, and rejected, if not (Assaf Neto \& Lima, 2011). The cost of capital, also called rate of return, discount rate, required return, or opportunity cost, is determined by decision makers themselves (Gitman, 2010). They aim at covering all aspects of return on committed capital during the whole project, which is why they consider factors such as inflation, sources of risk that undermine the capacity of the project to generate revenue (e.g., variation in sale prices and cost structure), and risk of variation in market interest rates (Lemes Júnior, Rigo, \& Cherobim, 2010).

All these factors weighted mathematically constitute the cost of capital, which can be understood as a Minimum Attractiveness Rate (MAR) demanded by investors to execute a particular project.

Comparing the recommendations for implementation of projects obtained by the NPV and IRR methods, Gitman (2010) affirms it is only possible to have conflicting classifications if the projects have very different durations from each other; the moment of occurrence of cash flows are at very different points in time line; or if the magnitude of initial investments and/or the cash flows generated in each project are not on the same scale.

Accordingly, this work does not meet any of the conditions mentioned above. All the boundary conditions of the study groups are similar, i.e., the maturation time of the projects (permanence of the study groups in the field), the moments when the cash flows were generated (cuts and sales), and their magnitude (price practiced by the market) are comparable. Therefore, with NPV and IRR methodologies, it can be said that it is possible to obtain a reliable representation of the capacity to generate value from each of the study groups.

The NPV is the most indicated method among academics. Ross et al. (2010) argue that NPV is the best choice for being both a measurement of value added and for the fact that IRR ignores the cash flow scale from different projects. According to Brigham and Ehrhardt (2012), NPV is the best tool to compare investment alternatives, as it is the one that best identifies and informs decision makers about the capacity to create wealth from an investment. 


\subsection{Profitability Index (PI)}

The profitability index, according to Ross et al. (2010), can be represented by the following equation:

$$
\mathrm{PI}=\frac{\text { Present value of cash flows subsequent to the investment }}{\text { Initial investment }}
$$

For Assaf Neto and Lima (2011), PI indicates how much a project returns for each monetary unit in present value. In this way, a profitability index (PI $>1$ ) represents an economically viable project that should be executed because it can generate value for the owners.

Brigham and Ehrhardt (2012) state the greater the PI of a project, the greater its classification. Accordingly to Ross et al. (2010), the PI is subject to the same IRR restrictions, so it must meet the same boundary conditions (projects with cash flows of the same magnitude and time proximity).

For projects independent of each other, the PI, NPV, and IRR will always result in the same acceptance-rejection decisions. For projects independent of each other, the PI, NPV, and IRR will always result in the same acceptance-rejection decisions (Brigham \& Ehrhardt, 2012). But in case of conflicting classifications of mutually excluding projects, the order of the projects according to NPV should be chosen (Ross et al., 2010).

\subsection{Analysis of Sensitivity}

For decision making, it bears in mind that many factors influence the budget of a project. Input and output prices have probabilistic variations. Predicting at what levels prices will be in the future is not an easy task. A number of external and internal factors affect the process. The analysis of sensitivity was applied to estimate the context. Analysis of sensitivity involves choosing the indicator to be sensitized, and determining its expression according to the parameters and variables chosen. In this manner, using a computer program, the results are achieved from the introduction of parameter values in the expression, the simulation is performed, and it is verified in what way and in what proportions these variables affect the result in terms of probabilities (Ponciano et al., 2004).

\subsection{Simulation Techniques}

To execute the simulations, it was chosen the Monte Carlo simulation method, which is based on the generation of random numbers. The Monte Carlo method is based on the distribution of continuous probability variables. As Triola (1999) says, the distribution function of continuous variables $y=F(x)$ is the sum of the probabilities of all possible values that the variable $\mathrm{x}$ can assume until the value of $\mathrm{x}$ itself. A continuous random variable (x) can assume any fractional value within a defined value range.

For a discrete random variable, the mathematical expectation is given as:

$$
\mathrm{E}(\mathrm{x})=\mathrm{x}_{1} \mathrm{P}\left(\mathrm{x}_{1}\right)+\mathrm{x}_{2} \mathrm{P}\left(\mathrm{x}_{2}\right)+\ldots+\mathrm{x}_{1 \mathrm{n}} \mathrm{P}\left(\mathrm{x}_{\mathrm{n}}\right)=\sum_{\mathrm{i}-1}^{\mathrm{n}} \mathrm{x}_{\mathrm{i}} \mathrm{P}\left(\mathrm{x}_{\mathrm{i}}\right)
$$

The probability density function is given by: $y=e^{-\frac{1}{2}\left(\frac{x-\mu}{\rho}\right)^{2}} / \rho \sqrt{2 \pi}$, where, $\mu$ is the distribution mean and $\rho$ is the standard deviation of the distribution. A standardized normal distribution that has a mean of 0 and the standard deviation equal to 1 , with tabulated results, in which $\mathrm{z}$ is the standardized normal variable, is determined by:

$$
\mathrm{z}=\frac{\mathrm{x}-\mu}{\sigma}
$$

The Monte Carlo simulation was used to prepare a cash flow model. It uses randomized numbers and probability to solve problems and has been widely applied in the literature (Peres et al., 2004; Lima et al., 2007; Mingoti \& Glória, 2008; Campos, 2010; Lyra et al., 2010; Sabbag \& Costa, 2015).

\section{Results and Discussion}

The cash flows were structured from the inflows and outflows of resources estimated in data collected in the region of the experiment, with a time frame of five years. It was observed in Table 1, a relationship between costs and the estimated profitability of dry matter, in which the local market pays the average price of $\mathrm{R} \$ 41.82$ (forty-one reais and eighty-two cents) per ton of dry matter of elephant grass for energy purposes. The sale price variation of grass is the characteristic that generates the greatest impact on the profitability of the activity, followed by the cost of labor and fertilization. 
Table 1. Cost and estimated profitability in dry matter (elephant grass) planted per hectare in the south region of the state of Espírito Santo, municipality of Alegre, 2013

\begin{tabular}{lll}
\hline \multirow{2}{*}{ Genotypes } & \multicolumn{2}{c}{ Cost and estimated profitability in dry matter (DM) } \\
\cline { 2 - 3 } & Cost in $\mathrm{R} \$ \mathrm{ha}$ & Estimated profitability in $\mathrm{R} \$$ \\
\hline G1 & 3196.18 & 3615.03 \\
G2 & 3196.18 & 3504.84 \\
G3 & 3196.18 & 3320.00 \\
\hline
\end{tabular}

According to Santos et al. (2014), when evaluating the effect of nitrogen and phosphate fertilization on the dry matter yield in this experiment, it was noticed that the mineral nutrients (nitrogen and phosphorus) did not generate, in general, relevant variations for the dry matter yield process and the average dry matter yield from the biomass of G1, G2, and G3 genotypes was 14.1567; 13.2277; and $11.5592 \mathrm{t} \mathrm{ha}^{-1}$, respectively. In the view of Santos et al. (2016), given the price of a ton of grass and the price of fertilizer, the use of nitrogen fertilizer in the production of elephant grass for energy purposes in the municipality of Alegre is not recommended.

The analysis of sensitivity showed that, in the systems proposed, the estimate of the sale price is the one that has the greatest impact on profitability. Variables such as the growing system, labor, and agricultural inputs were considered important for the success of the project because of their relevance related to the costs of the project. The NPV with a planning horizon was positive for all the discount rates taken into account. To determine the minimum attractiveness rate (MAR) of $9 \%$ per year, it was considered the equity and the value close to the average evolution of the Selic rate between 2008 and 2012. In order of importance, the genotypes with the highest values were G1, G2, and G3, respectively. The profitability indexes obtained for the three genotypes analyzed were depicted in Table 2 .

Table 2. Net Present Value and Internal Rate of Return related to the planting of elephant grass planting in the region of Alegre, south of the state of Espírito Santo in 2013

\begin{tabular}{llllllll}
\hline \multirow{2}{*}{ Genotypes } & \multicolumn{7}{c}{ Net Present Valueo (R\$) } \\
\cline { 2 - 7 } & $1.50 \%$ & $3.00 \%$ & $4.50 \%$ & $6.00 \%$ & $7.50 \%$ & $9.00 \%$ & IRR \\
\hline G1 & 1365.52 & 1203.04 & 1049.69 & 904.81 & 767.78 & 638.06 & $17.79 \%$ \\
G2 & 1065.69 & 913.89 & 770.62 & 635.26 & 507.24 & 386.04 & $14.39 \%$ \\
G3 & 629.66 & 493.75 & 365.47 & 244.27 & 129.65 & 21.14 & $9.31 \%$ \\
\hline
\end{tabular}

Considering the estimated values for the IRR(s), all activities are recommended, as they showed values above the MAR equal to $9.0 \%$. Taking into account the order of importance, there was the following information: G1 with $\mathrm{IRR}=17.79 \%$; G2 with $\mathrm{IRR}=14.39 \%$; and G3 with $\mathrm{IRR}=9.31 \%$.

For the G1, G2, and G3 genotypes, an internal rate of return (IRR) of $17.79 \%, 14.39 \%$, and $9.30 \%$ were estimated, respectively. The decreasing behaviors of NPV(s) relative to the respective MAR(s) for G1, G2, and G3 are depicted in Figures 1, 2, and 3. 


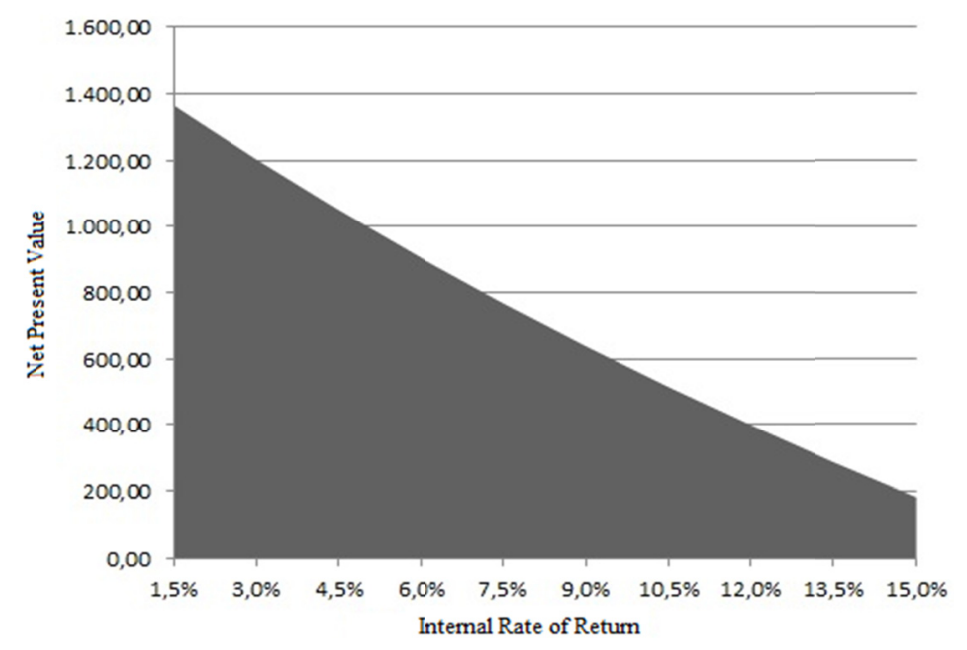

Figure 1. Behavior of NPV with the MAR relative to the G1 genotype

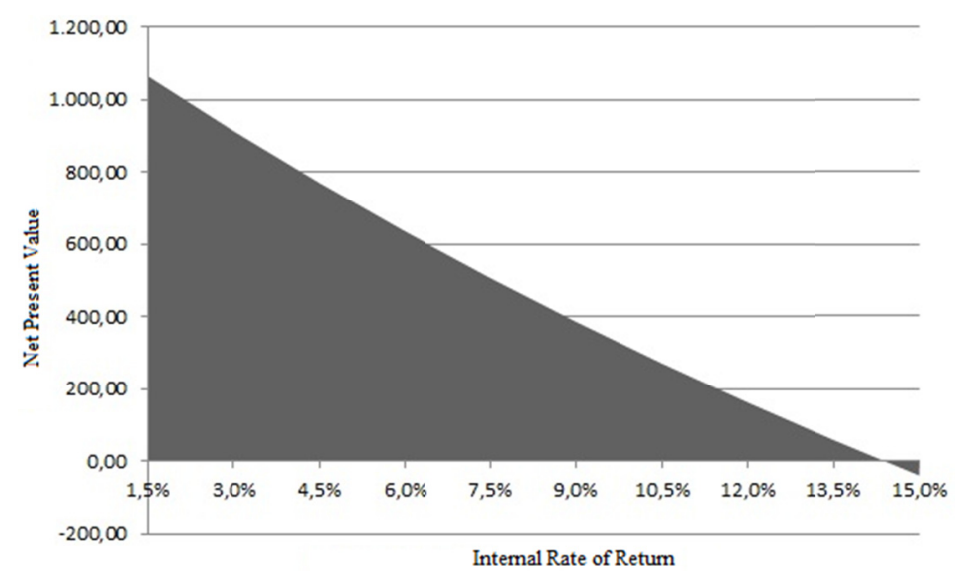

Figure 2. Behavior of NPV with the MAR relative to the G2 genotype

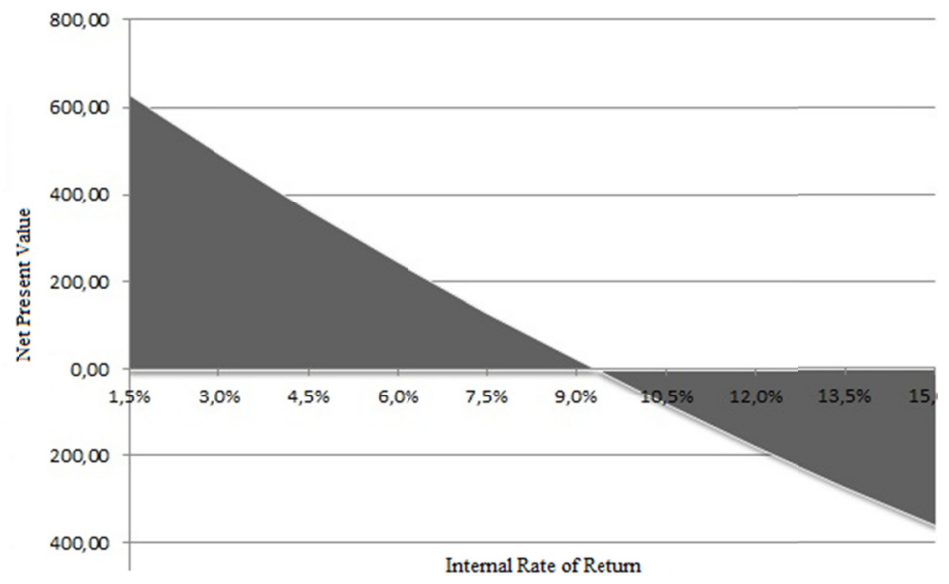

Figure 3. Behavior of NPV with the MAR relative to the G3 genotype

In the Monte Carlo simulation, the estimated NPV value for the G1 genotype was of R $\$ 418.85$, for an estimated IRR of $13.63 \%$; for G2, the value was of R $\$ 306.66$, for an estimated IRR of $11.94 \%$; and, for G3, of R $\$ 121.82$, for an estimated IRR of $9.31 \%$. 
The cumulative probability distributions of the net present values for the G2 and G3 genotypes were smaller than for the G1 genotype. The probability estimated for negative net present values (NPV $<0$ ) of the G1 genotype was $1.8 \%$; of G2 was $5.49 \%$; and of G3 genotype was $38.16 \%$. The NPV estimate of the G1 genotype was greater than the NPV estimates of the G2 and G3 genotypes. As such, the risk of failure was relatively low, with the exception of Capim Cana D'Africa (G3), 38.16\%.

In Figure 4, it was verified the cumulative probability distribution of the net present value from the Monte Carlo simulation. Since this is a simulation, it should be observed that the cash flows estimated are susceptible to error. Yet, the information collected should not be neglected, as it greatly contributes to decision making.

The PI estimated, in order of importance, were 1.131 for the G1 genotype; 1.096, for G2; and 1.038, for G3. As they are estimates, cash flow projections are subject to errors. The determination of risk estimates was limited since, besides the economic risks, the climatic risks of the region in which the project was conducted were also taken into account.

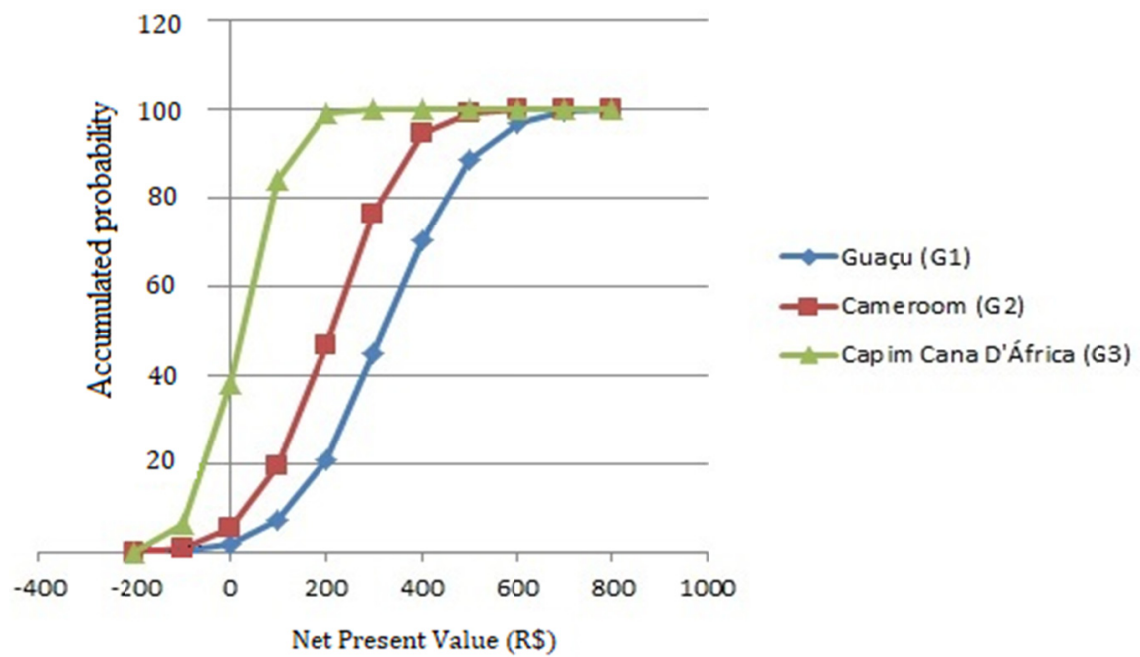

Figure 4. Accumulated probability distribution of the net present value (NPV) obtained in the Monte Carlo Simulation of the Guaçú/I.Z.2 (G1), Cameroon Piracicaba (G2), and Capim Cana D'Africa (G3) genotypes in the municipality of Alegre, state of Espírito Santo, Brazil

\section{Conclusions}

This study hopes to bring contributions by revealing information that helps decision-making and search for strategies that allow better profitability for the producer.

The genotypes discussed in this work were economically viable and the risk of not reaching success was relatively low.

The risk of not reaching success was relatively low, with the exception of the G3 genotype (Capim Cana D'Africa).

The Guaçú/I.Z.2 genotype was highlighted as the genotype with the best economic viability and the lowest risk of failure for energy purposes in the municipality of Alegre, state of Espírito Santo, Brazil.

\section{References}

Aerieira, C. R. D., Dos Santos Morita, D. A., Aieira, J. O., \& Codato, J. M. (2008). Análise da viabilidade econômica para produção de flores em Umuarama, noroeste do Paraná. Revista Agro@mbiente On-line, 2(2), 33-41.

Assaf Neto, A., \& Lima, F. G. (2011). Curso de Administração Financeira. São Paulo: Atlas.

Borges, P. C. A., Silva, S. M., Alves, T. C., \& Torres, A. E. (2016). Energias renováveis: Uma contextualização da biomassa como fonte de energia. Revista Eletrônica do PRODEMA, 10(2). https://doi.org/10.22411/ rede2016.1002.02 
Campos, R. T. (2010). Avaliação sob risco da capacidade de pagamento por água bruta de produtores da Bacia do Jaguaribe (CE). Revista de Economia e Sociologia Rural, 48(2), 357-380. https://doi.org/10.1590/ S0103-20032010000200005

Ehrhardt, M. C., \& Brigham, E. F. (2012). Administração Financeira: Teoria e Prática. São Paulo: Cengage Learning.

EMBRAPA, Centro Nacional de Pesquisa de Solos, RJ. (2013). Sistema brasileiro de classificação de solos. Brasília, DF.

Ferraz Carvalho, C. R., Ponciano, N. J., De Souza, P. M., Melo De Souza, C. L., \& Fernandes De Sousa, E. (2014). Viabilidade econômica e de risco da produção de tomate no município de Cambuci/RJ, Brasil. Ciência Rural, 44(12). https://doi.org/10.1590/0103-8478cr20131570

Gitman, L. J. (2010). Princípios de Administração Financeira. Tradução de Allan Vidigal Hastings. São Paulo: Pearson Prentice Hall.

Guiducci, R. do C. N., Alves, E. R. de A., Lima Filho, J. R., \& Mota, M. M. (2012). Aspectos metodológicos da análise de viabilidade econômica de sistemas de produção. In R. do C. N. Guiducci, J. R. Lima Filho, \& M. M. Mota (Eds.), Viabilidade econômica de sistemas de produção agropecuários: Metodologia e estudos de caso (pp. 17-78). Brasília, DF: Embrapa.

Lemes Júnior, A. B., Rigo, C. M., \& Cherobim, A. P. M. S. (2010). Administração Financeira: Princípios, Fundamentos e Práticas Brasileiras. Rio de Janeiro: Elsevier.

Lima, E. A., Coelho, F. C., Bastiani, M. L. R., Golynski, A., Ponciano, N. J., \& Lima, A. A. (2007). Avaliação econômica e de risco de soja em rotação com cana-de-açucar na Região Norte Fluminense. Acta Scientiarum Agronomy, 29(3), 403-409. https://doi.org/10.4025/actasciagron.v29i3.392

Lima, J. S. De S., Silva, S. De A., Oliveira, R. B. De, Cecílio, R. A., \& Xavier, A. C. (2008). Variabilidade temporal da precipitação mensal em Alegre-ES. Revista Ciência Agronômica, 39(2).

Lyra, G. B., Poncia.no, N. J., De Souza, P. M., De Souza, E. F., \& Lyra, G. B. (2010). Viabilidade econômica e risco do cultivo de mamão em função da lâmina de irrigação e doses de sulfato de amônio. Acta Scientiarum Agronomy, 32(3), 547-554. https://doi.org/10.4025/actasciagron.v32i3.2451

Mingoti, S. A., \& Glória, F. A. A. (2008). Comparing Mingoti and Glória's and Niverthi and Dey's multivariate capability indexes. Produção, 18(3), 598-608. https://doi.org/10.1590/S0103-65132008000300014

Mohammed, I. Y., Abakr, Y. A., Kazi, F. K., Yusup, S., Alshareef, I., \& Chin, S. A. (2015). Comprehensive Characterization of Napier Grass as a Feedstock for Thermochemical Conversion. Energies, 8, 3403-3417. https://doi.org/10.3390/en8053403

Morais, R. F., Souza, J. B., Leite, J. M., Soares, L. H. B., Alves, B. J. R., Boddey, R. M., \& Urquiaga, S. (2009). Elephant grass genotypes for bioenergy production by direct biomass combustion. Pesquisa Agropecuária Brasileira, 44(2), 133-140. https://doi.org/10.1590/S0100-204X2009000200004

Noronha, J. F. (1987). Projetos agropecuários: Administração financeira, orçamento e viabilidade econômica. São Paulo: Atlas.

Paterlini, E. M., Arantes, M. D. C., Gonçalves, F. G., Vidaurre, G. B., De Oliveira Bauer, M., \& Moulin, J. C. (2013). Evaluation of elephant grass for energy use. Journal of Biotechnology and Biodiversity, 4(2), 119-125. https://doi.org/10.20873/jbb.uft.cemaf.v4n2.paterlini

Pereira, T., Rangel, R., Rodrigues, A., Azevedo, R., \& Pena, H. W. A. (2011). Análise de viabilidade econômica de uma plantação de eucalipto no Pará-Amazônia-Brasil. Observatorio de la Economía Latinoamericana (p. 159).

Peres, A. A. C., De Souza, P. M., Maldonado, H., Da Silva, J. F. C., Soares, C. S., Barros, S. C. W., \& Haddad, I. R. (2004). Análise econômica de sistemas de produção a pasto para bovinos no Município de Campos dos Goytacazes-RJ. Revista Brasileira de Zootecnia, 33(6), 1557-1563. https://doi.org/10.1590/S1516-359820 04000600023

Ponciano, N. J., Souza, P. M., Costa Mata, H. T., Vieira, J. R., \& Morgado, I. F. (2004). Análise de viabilidade econômica e de risco da fruticultura na região norte fluminense. Revista de Economia e Sociologia Rural, 42(4). https://doi.org/10.1590/S0103-20032004000400005 
REN 21 (Renewable Energy Policy Network for the 21st Century). (2013). Renewables 2013: Global Status Report.

Ross, S. A., Westerfield, R. W., \& Jaffe, J. (2010). Corporate Finance. New York: Mcgraw-ill/Irwin.

Ross, S. A., Westerfield, R. W., \& Jordan, B. D. (2008). Administração Financeira. São Paulo: Amgh Editora.

Sabbag, O. J., \& Costa, S. M. A. L. (2015). Análise de custos da produção de leite: Aplicação do método de Monte Carlo. Extensão Rural, 22(1), 125-145. https://doi.org/10.5902/2318179614153

Sabbag, O. J., \& Nicodemo, D. (2011). Viabilidade econômica para produção de mel em propriedade familiar. Pesquisa Agropecuária Tropical, 41(1), 94-101. https://doi.org/10.5216/pat.v41i1.10414

Santos, M. M. P., Daher, R. F., Ponciano, N. J., De Amaral Gravina, G., Vander Pereira, A., De Almeida Sant'ana, J. A., \& Santos, C. L. (2014). Características produtivas de capim-elefante sob doses de fósforo e nitrogênio para fins energéticos. Cientifica, 42(4), 354-365. https://doi.org/10.15361/1984-5529.2014v42n4p354-365

Santos, M. M. P., Ponciano, N. J., Daher, R. F., Gravina, G. A., Pereira, A. V., \& Santos, C. L. (2016). Otimização azotada no capim-elefante para fins energéticos. Revista de Ciências Agrárias, 39(3), 366-375. https://doi.org/10.19084/RCA15122

Triola, M. F. (1999). Introdução a estatística (7th ed.). Rio de Janeiro: LTC.

Van Der Selt, M. J. C., Gerhauser, H., Kiel, J. H. A., \& Ptasinski, K. J. (2011). Biomass upgradings by torrefaction for the production of biofuels: A review. Biomass and Bioenergy, 35, 3748-3762. https://doi.org/10.1016/j.biombioe.2011.06.023

\section{Copyrights}

Copyright for this article is retained by the author(s), with first publication rights granted to the journal.

This is an open-access article distributed under the terms and conditions of the Creative Commons Attribution license (http://creativecommons.org/licenses/by/4.0/). 